
$(200)$
T676
No. 133

\title{
The Design of the Model V Transmission Fluorimeter
}

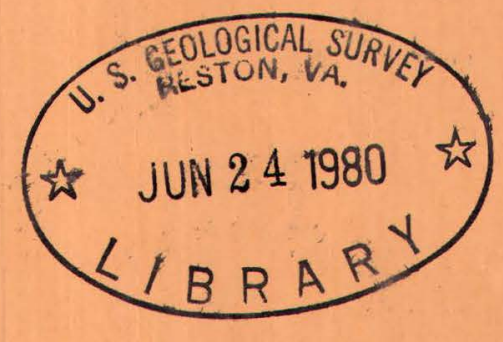

\section{Trace Elements Investigations Report 133}

UNITED STATES DEPARTMENT OF THE INTERIOR GEOLOGICAL SURVEY 
UNITED STATES DEPARTMENT OF THE INTERIOR

GEOLOGICAL SURVEY

THE DESIGN OF THE MODEL V TRANSMISSION FLUORIMETER

by

Mary H. Fletcher, Irving May, and Joseph W. Anderson

Deck mber 1950

Trace Elements Investigations Report 133 
USGS-TEI Rept. 133

Consisting of 5 pages

Issued to (see below)

The distribution of this report is as follows:

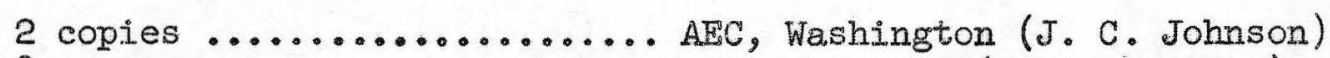

8 copies .................AEC, New York (P. L. Merritt)

1 copy .................... WEC, Washington (J. O. Hosted)

1 copy $\ldots \ldots \ldots \ldots \ldots \ldots \ldots \ldots \ldots$ AEC, Denver (C. C. Towle, Jr.)

1 copy.$\ldots \ldots \ldots \ldots \ldots \ldots \ldots \ldots$ AEC, Spokane (E. E. Thurlow)

$I$ copy ................... AEC, Grand Junction (T. W. Oster)

I copy ................. IMC, Mulberry, Fla. (I. M. LeBaron)

1 copy..$\ldots \ldots \ldots \ldots \ldots \ldots \ldots$ Dow Chemica.I Co., Pittsburg, Calif.

(G. I. Allen)

1 copy ................... MIT, Watertown, Mass. (John Dasher)

1 copy $\ldots \ldots \ldots \ldots \ldots \ldots \ldots \ldots$ ORNL, $\mathrm{Y}-12$, Oa.k Ridge (Glenn Clewett)

1 copy ................. USGS, Washington (Mineral Deposits Branch)

1 copy..$\ldots \ldots \ldots \ldots \ldots \ldots$ USGS, Washington (Fuels Branch)

1 copy .................. USGS, Washington (Alaska Branch)

28 copies ................ USGS, Washington (Geochemistry and

1 copy $\ldots \ldots \ldots \ldots \ldots \ldots \ldots \ldots$ USGS, Washington (V. E. McKelvey)

I copy .................. USGS, Plant City, FIa. (J. B. Cathcart)

1 copy ................. USGS, Grand Junction (R. P. Fischer)

I. copy $\ldots \ldots \ldots \ldots \ldots \ldots \ldots$. USGS, Denver (I. R. Page)

1 copy $\ldots \ldots \ldots \ldots \ldots \ldots \ldots \ldots$ USGS, Spokane (A. E. Weissenborn)

3 copies $\ldots \ldots \ldots \ldots \ldots \ldots$ USGS, Washington (TEPCO)

(including master copy) 
CONFENIS

Page

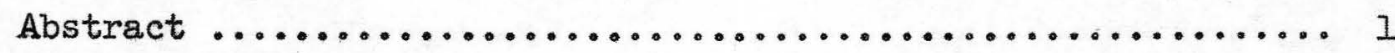

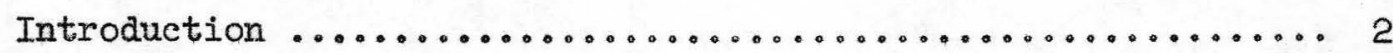

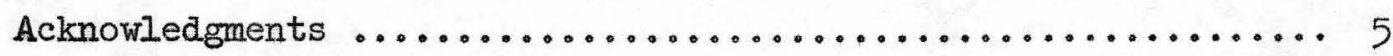

ILIUSTRATIONS

Following

page

Figure 1. Fluorimeter assembly ................... 5

2. "Fluorimeter" -- cut-away and cross-section ....... 5

3. Details of parts shown in figure $2 \ldots \ldots \ldots . . . . .5$

4. Details of parts shown in figure $2 \ldots \ldots \ldots . . . . .5$

5. Details of parts shown in figure $1 \ldots \ldots \ldots . \ldots$

6. Details for construction of shield ............ 5

7. Details for construction of type-B phototube housing ................ 5 
THE DESIGN OF THE MODEL V TRANSMISSION FLUORIMETER

by

Mary H. Fletcher, Irving May, and Joseph W. Anderson

\section{ABSTRACT}

A transmission fluorimeter for the measurement of the fluorescence of uranium in fluoride melts is described. The instrument incorporates several improved features which have not been published previously. Unlike the earliest models, the design of the new fluorimeter, with its close machining of parts, reduces the possibility of light leakage and also increases considerably the ease with which the various components of the instrument may be assembled and adjusted. The Model $\mathrm{V}$ fluorimeter is a very rugged instrument with a compact arrangement of parts. It possesses great flexibility so that various phototubes, measuring devices, light sources, and filter combinations may be used interchangeably.

Detailed shop drawings are given for the construction of the fluorimeter. 


\section{INTIRODUCTION}

The use of transmission fluorimeters for the measurement of the fluorescence of uranium in fluoride melts has been discussed in other papers.1,2,3,4/ The ModeI II fluorimeter was described 1,2/ without detailed drawings inasmuch as it was an experimental model.

Newer models have been built, and the Model $\mathrm{V}$ instrument described in this paper incorporates the various improved features of these instruments. No further marked changes in design are contemplated, and therefore we are presenting detailed drawings of the instrument.

Like earlier models, the Model $\mathrm{V}$ was designed to be a rugged, light-tight instrument, with compact arrangement of parts and great flexibility. Various phototubes, measuring devices, light sources, and filter combinations may be used interchangeably. The chief difference between the two "fluorimeters" is that the Model II is rectangular whereas the Model $\mathrm{V}$ is cylindrical. If Fletcher, Mary H., U. S. Geol. Survey, Trace Elements Inves-
tigations Rept. 130 (in preparation).

2/ Fletcher, Mary H., May, Irving, and Slavin, Morris, A transmission fluorimeter for use in the fluorimetric method of analysis for uranium: U. S. Geol. Survey, Trace Elements Investigations Rept. 104, August 1949.

3/ May, Irving, and Fletcher, Mary H., A preliminary report on a transmission fluorimeter: U. S. Geol. Survey, Report TWC-184, 1948.

4/ May, Irving, and Fletcher, Mary H., A battery-powered fluorimeter for the determination of uranium: U. S. Geol. Survey, Trace Elements Investigations Rept. 135 (in preparation). 
For clarity the word "fluorimeter," in quotation marks, as used. in this paper refers to that part of the complete fluorimeter which houses the filters, sample slide, and shutter.

The Model V "fluorimeter" is machined from solid brass. The "fluorimeter" head includes the sample slide, shutter, and a holder for the primary filters. The sample slide is provided with adaptors so that several sizes of fluoride melts may be accormodated. The secondary filters are in the bottom plate which screws into the "fluorimeter" head. The bottom plates are of two types-A and B. Type A is used with an RCA-IP2l photomultiplier tube or with the Photovolt Electronic Photometer (Model 512). It is threaded to fit the Photovolt search unit. Housings for the IP2l photomultiplier tubes were built to have the same thread as the Photovolt search unit so that either phototube can be used with the type-A plate. The type-A plate is constructed so that phototube housings can be removed or installed while the fluorimeter is in position on the supporting stand. The type-B bottom plate is used with the RCA 5819 photomultiplier tube. The Cinch No. $3 \mathrm{MI} 4$ socket with mounting ring 3RI4 is used with this tube.

The filter holders are made for two-inch-square filters. An adaptor ring for each filter holder permits the use of filters of different thicknesses.

The instrument is shown in detail in figures 1 - 7. In figure 1, one-half of drawing $A$ is a section showing the fluorimeter assembly with type-A bottom plate and Photovolt search unit in place; figure I, 
drawing $B$ shows the arrangement with type-B bottom plate and RCA 5819 photomultiplier tube. The stand, lamp support, and shield are the same for both arrangements. Figure 2 is a cut-away drawing showing additional details of the "fluorimeter." The remaining figures are detailed shop drawings for the construction of parts shown in figures 1 and 2. All parts of the "fluorimeter" shown in figures 3 and 4 must be machined to a class -4 fit or better; those shown in figure 5 need be only a class -3 fit.

A thin glass disc (not shown in the figures) is required in the sample slide under the adaptor ring. The purpose of this disc is to prevent flakes of the sample from falling into the fluorimeter. This glass must be nonfluorescent. We have found that discs cut from photographic plates used in spectrum analysis are satisfactory. The lamp shown in figure 1 is a General Electric EH-4 or $\mathrm{CH}-4$ lamp. This lamp requires a porcelain socket with an admedium base. It is operated with a Sola. No. 30, 852 Constant Voltage Transformer designed especially for $\mathrm{H}-4$ lamps. The lamp temperature is controlled by ventilation with a "Bon-Air" Darkroom Ventilator.

The primary filters are two-inch-square Corning No. 5874 ultraviolet filters, polished thickness. Two of these filters are generally used. The secondary filters may be either a combination of Corning filters No. 3486 and 9780, moulded or polished thickness, or an interference filter peaked for maximum transmission at 5550A. Various combinations of phototubes, and current amplifying and 
measuring devices which may be used with this "fluorimeter" have been described elsewhere.5,6/

\section{ACKMOWLEDGMENTS}

We gratefully acknowledge the contributions to this project by our associates at the U. S. Geological Survey.

We are especially indebted to Alexander E. Herold, Jr., who did all of the machine work and made many valuable contributions to the final design.

Special thanks are also due to Joseph Ramish who assisted in the original design, and to John V. Waitowitz, Melvin E. Hanes, and Karl M. Kozee who prepared the drawings appearing in this paper.

5/ Fletcher, Mary H., May, Irving, and Slavin, Morris, A transmission fluorimeter for use in the fluorimetric method of analysis for uranium: U. S. Geol Survey, Trace Elements Investigations Rept. 104, August 1949.

6/ May, Irving, and Fletcher, Mary H., A battery-powered fluorimeter for the determination of uranium: U. S. Geol. Survey, Trace Elements Investigations Rept. 135 (in preparation). 


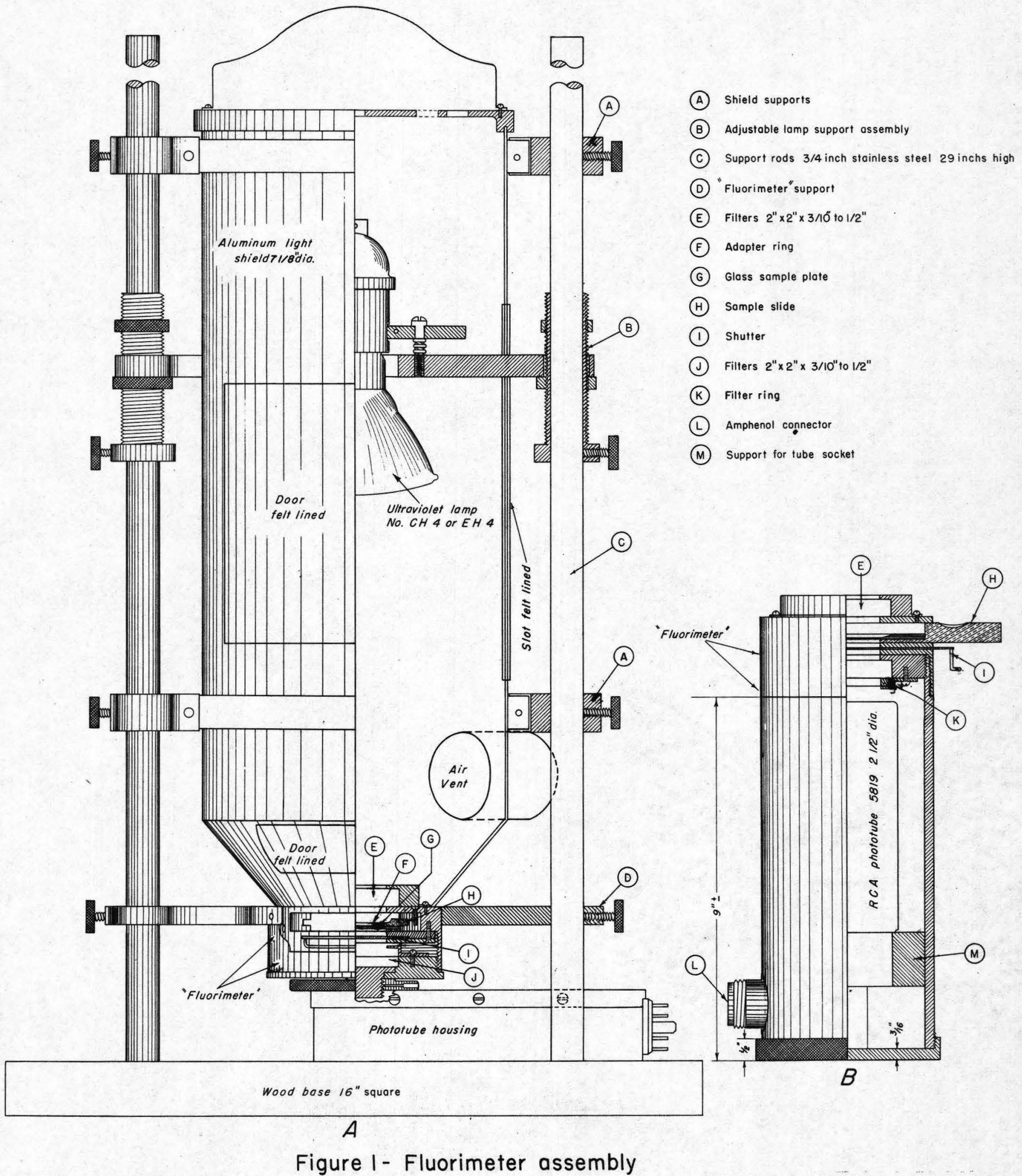



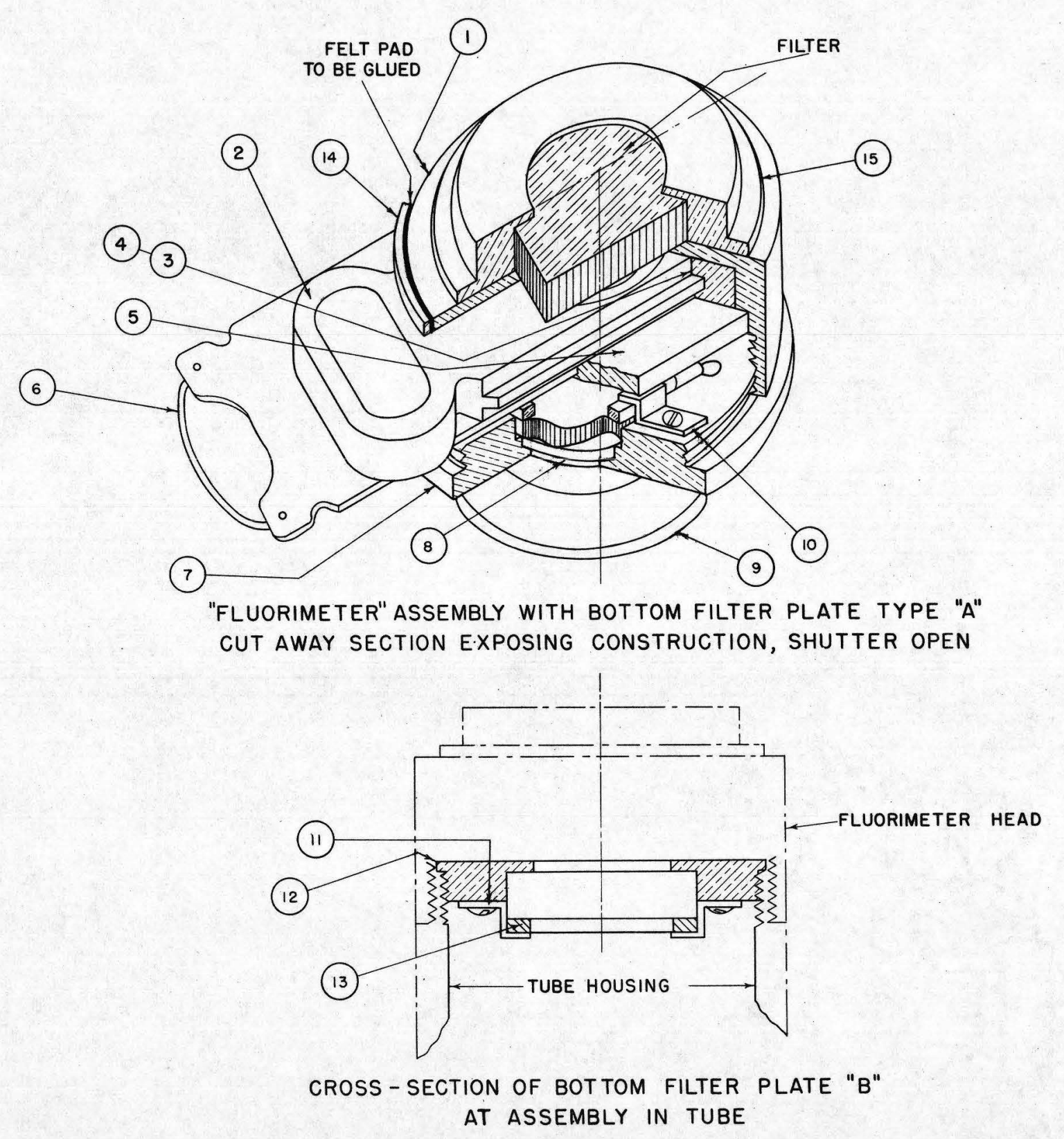

\begin{tabular}{|c|c|c|c|c|c|}
\hline & SLIDE ADAPTER RING & & 4 & BRASS & SHEET \\
\hline & FLAT HEAD SCREW & No. $6-32 x^{5} / 16$ & 4 & 1 & \\
\hline & FLAT HEAD SCREW & No. $8-32 \times 5 / 8$ & 4 & 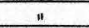 & \\
\hline & BOLT & $2-56 \times 1 / 8$ & 1 & 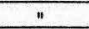 & \\
\hline & HDLS. SET SCREW & No. $4-40 \times 3 / 8$ & 1 & 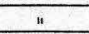 & \\
\hline & BUTTON HD. SCREW & No. $4-40 x^{1 / 4}$ & 12 & II & \\
\hline & BUTTON HD. SCREW & No. $8-32 x^{1 / 4}$ & 2 & 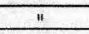 & \\
\hline 15 & TOP PLATE & & 1 & 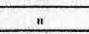 & FIG. 4 \\
\hline 14 & BLACK OUT PLATE & & $\frac{1}{1}$ & I & 4 \\
\hline 13 & FILTER RING & & 2 & 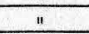 & 114 \\
\hline 12 & FILTER PLATE & & 1 & " & " 4 \\
\hline II & FILTER CLIP & & $\frac{1}{4}$ & " & 13 \\
\hline 10 & FILTER CLIP & & 4 & " & 113 \\
\hline 9 & SPANNER NUT & & 1 & 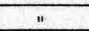 & 114 \\
\hline 8 & PLATE FLANGE & & 1 & " & 14 \\
\hline 7 & BOT TOM FILTER PLATE & & 1 & in & 114 \\
\hline 6 & SHUTTER & & 1 & 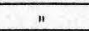 & 13 \\
\hline 5 & SHUTTER SLIDE & & 1 & " & \\
\hline 4 & SLIDE GUIDE L.H. & & $\frac{1}{1}$ & 4 & 113 \\
\hline 3 & SLIDE GUIDE R.H. & & 1 & $"$ & 1. 3 \\
\hline 2 & SAMPLE SLIDE & & $i$ & $"$ & 113 \\
\hline $\mathrm{T}$ & FLUORIMETER HOUSING & & $i$ & BRASS & FIG. 3 \\
\hline & & & & & \\
\hline
\end{tabular}

ALL FITTINGS TO BE LIGHT TIGHT

Figure 2 - "Fluorimeter" - cut-away and and cross-section 

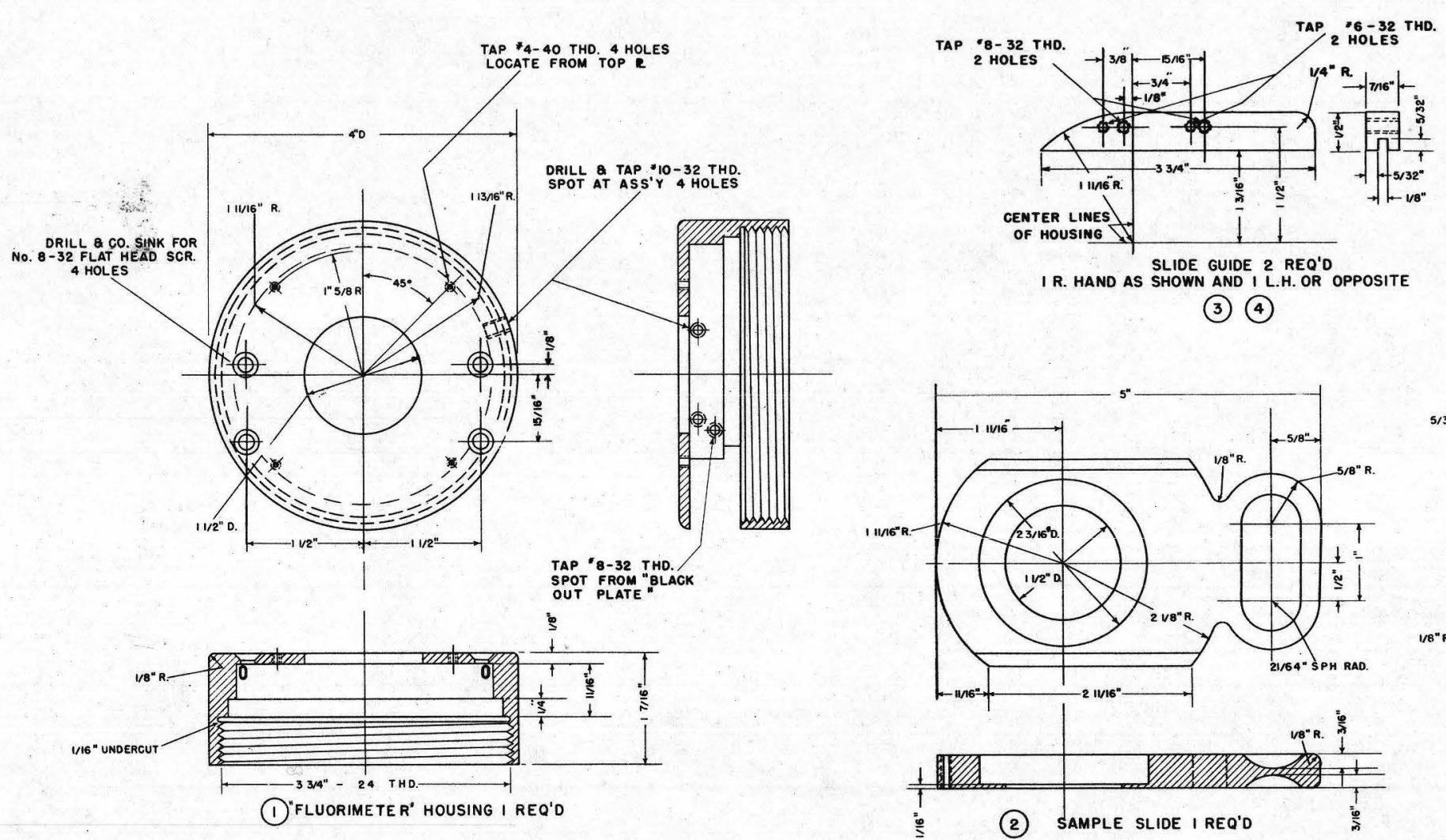

I R. HAND AS SHOWN AND I L.H. OR OPPOSITE

(3) (4)
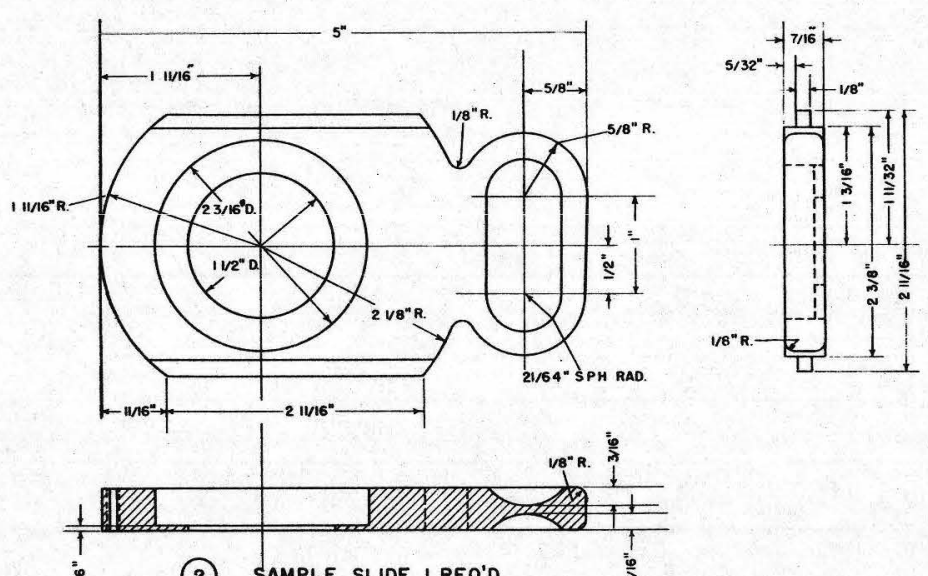

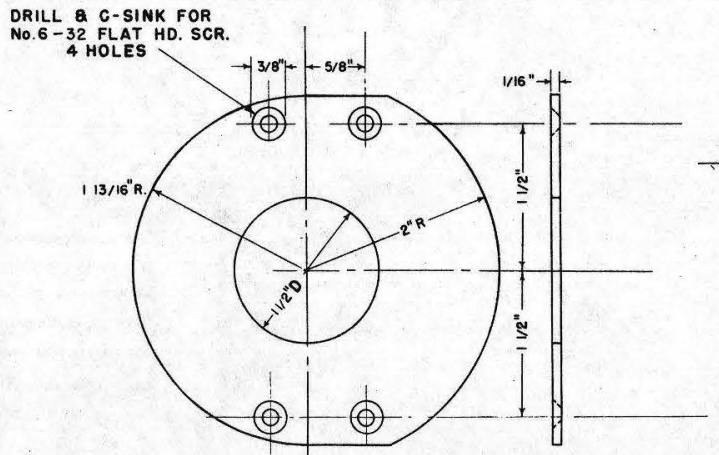

(5) Shutter plate I req'o

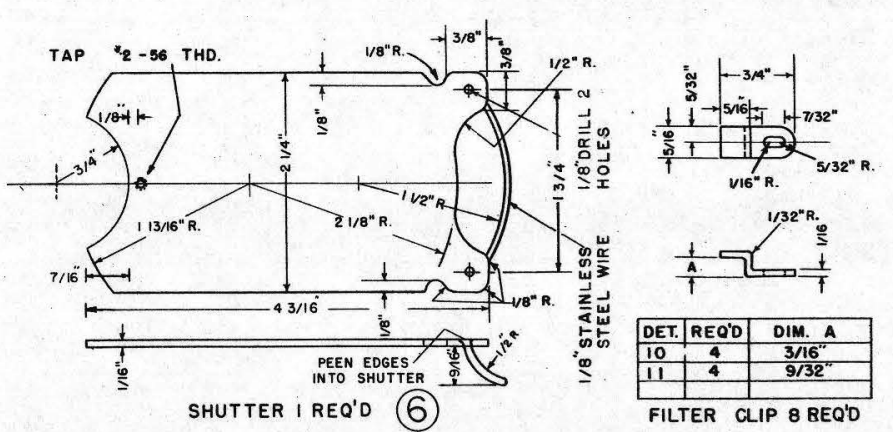

(10) (11)

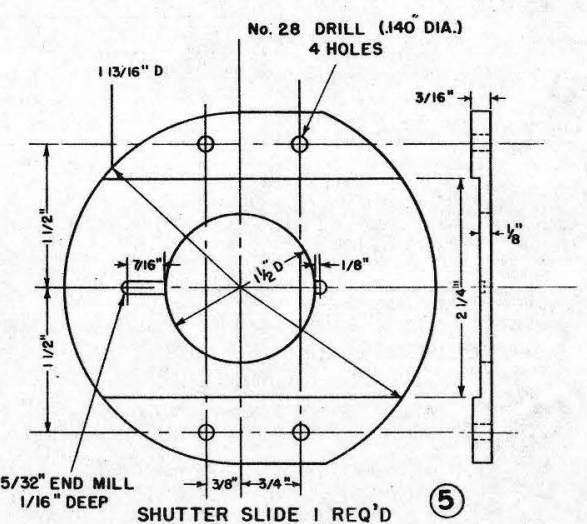

Figure 3-Details of parts shown in Figure 2 

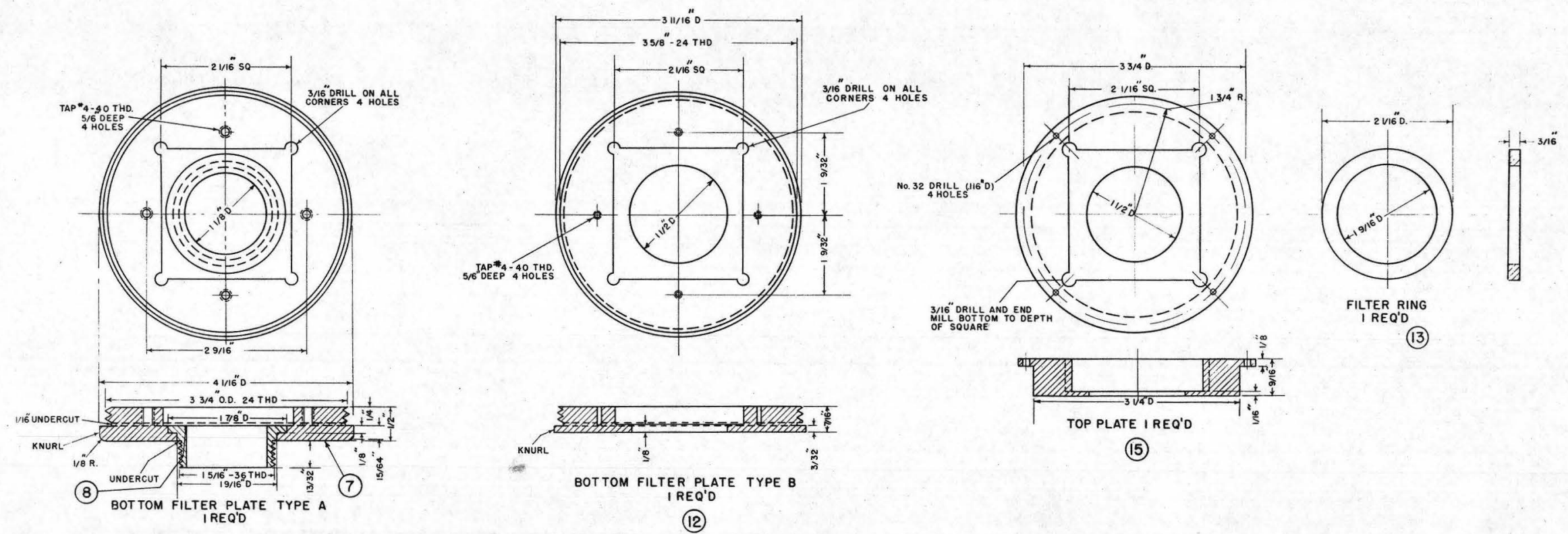

(13)

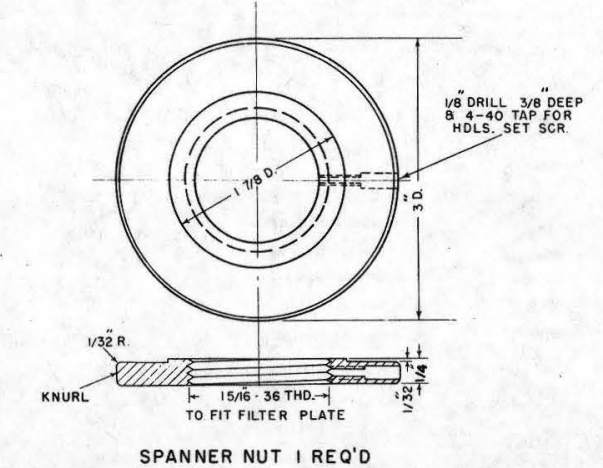

(9)

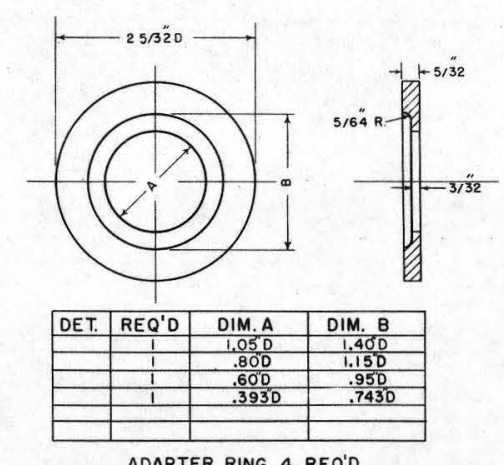

ADAPTER RING 4 REQ'D

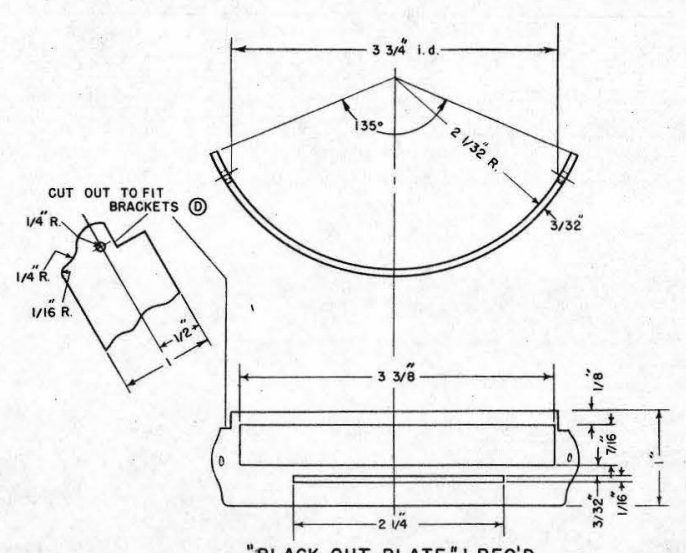

"BLAGK OUT PLATE"I REQ'D
EXTENDED LENGTH

Figure 4-Details of parts shown in Figure 2 

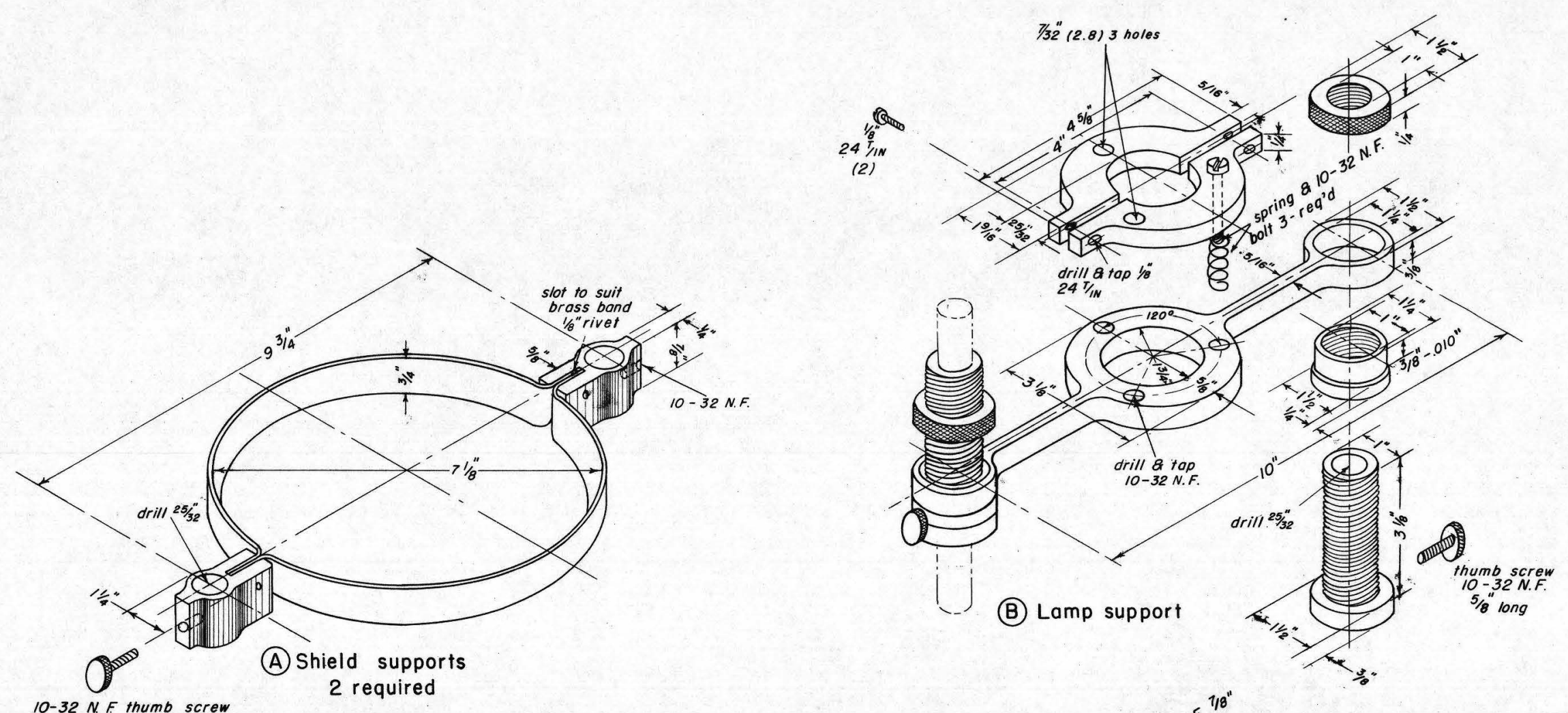

2 required
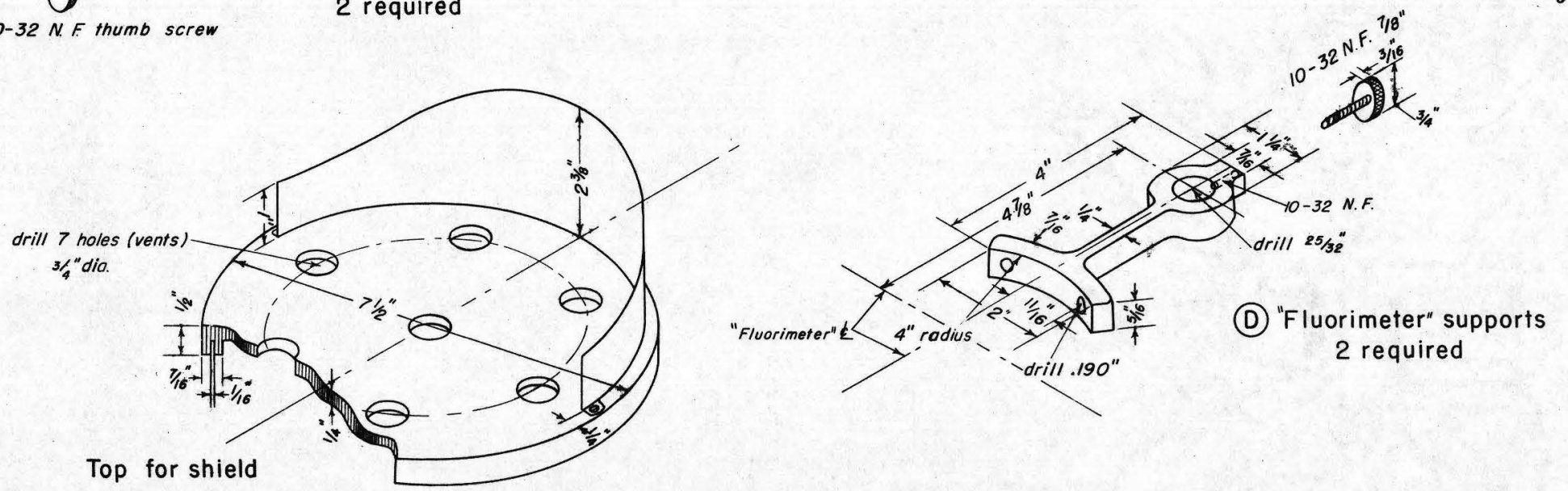

Figure 5- Details of parts snown in rigure I 


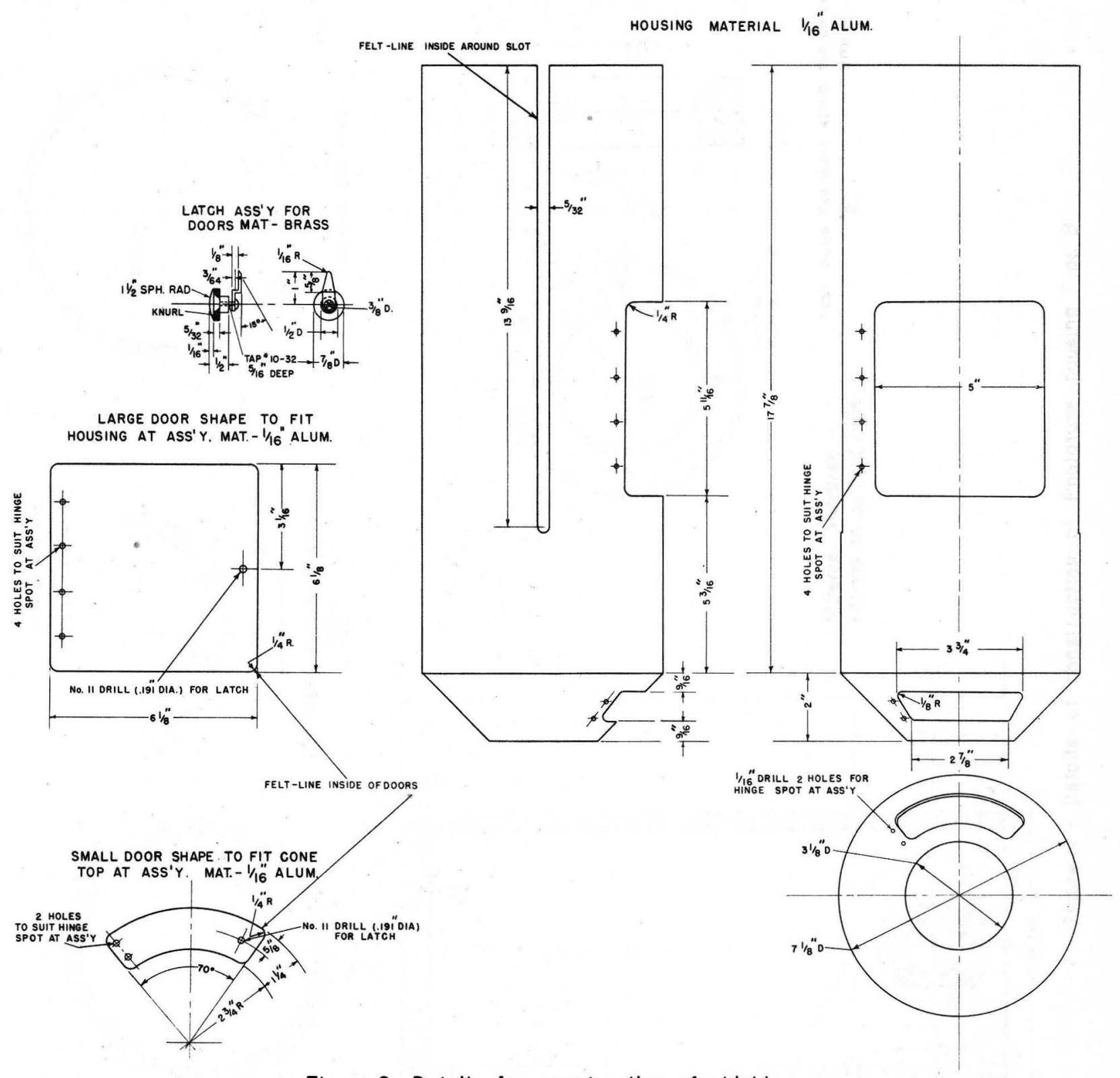

Figure 6-Details for construction of shield 


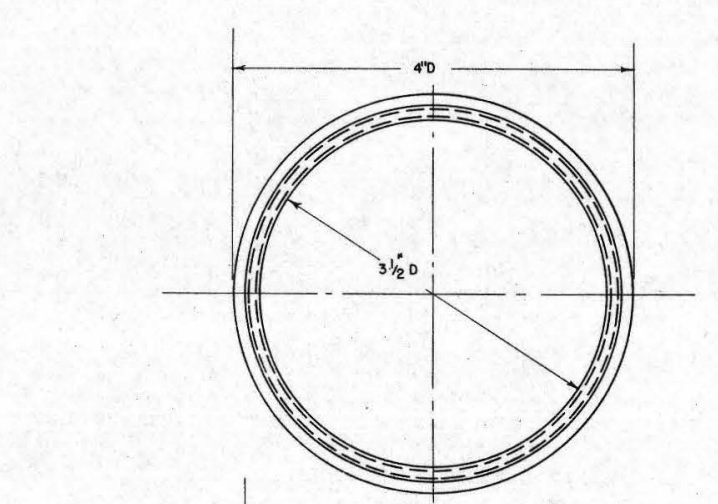

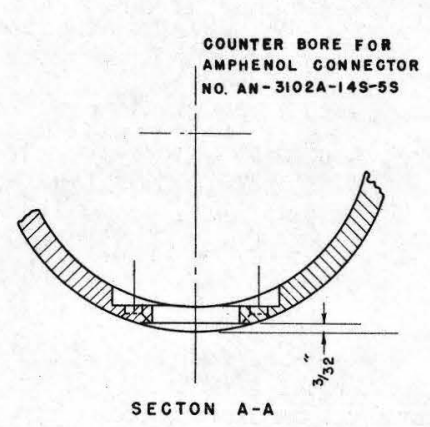

PHOTOTUBE HOUSING I REQ'D

(1)

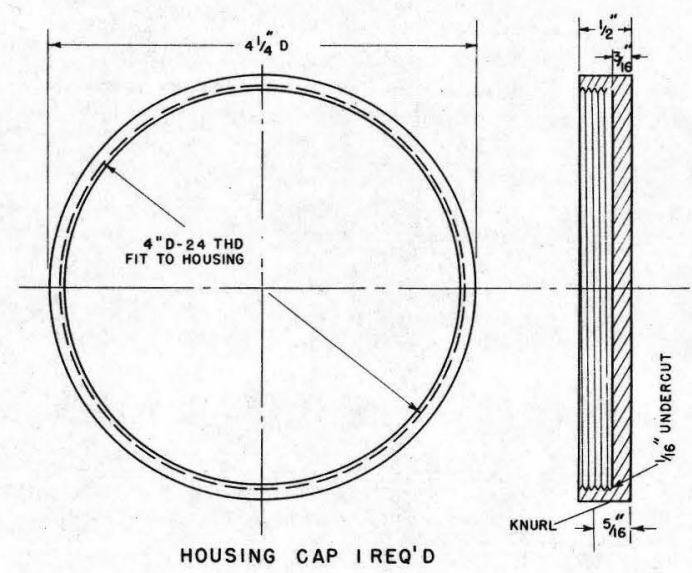

(3)
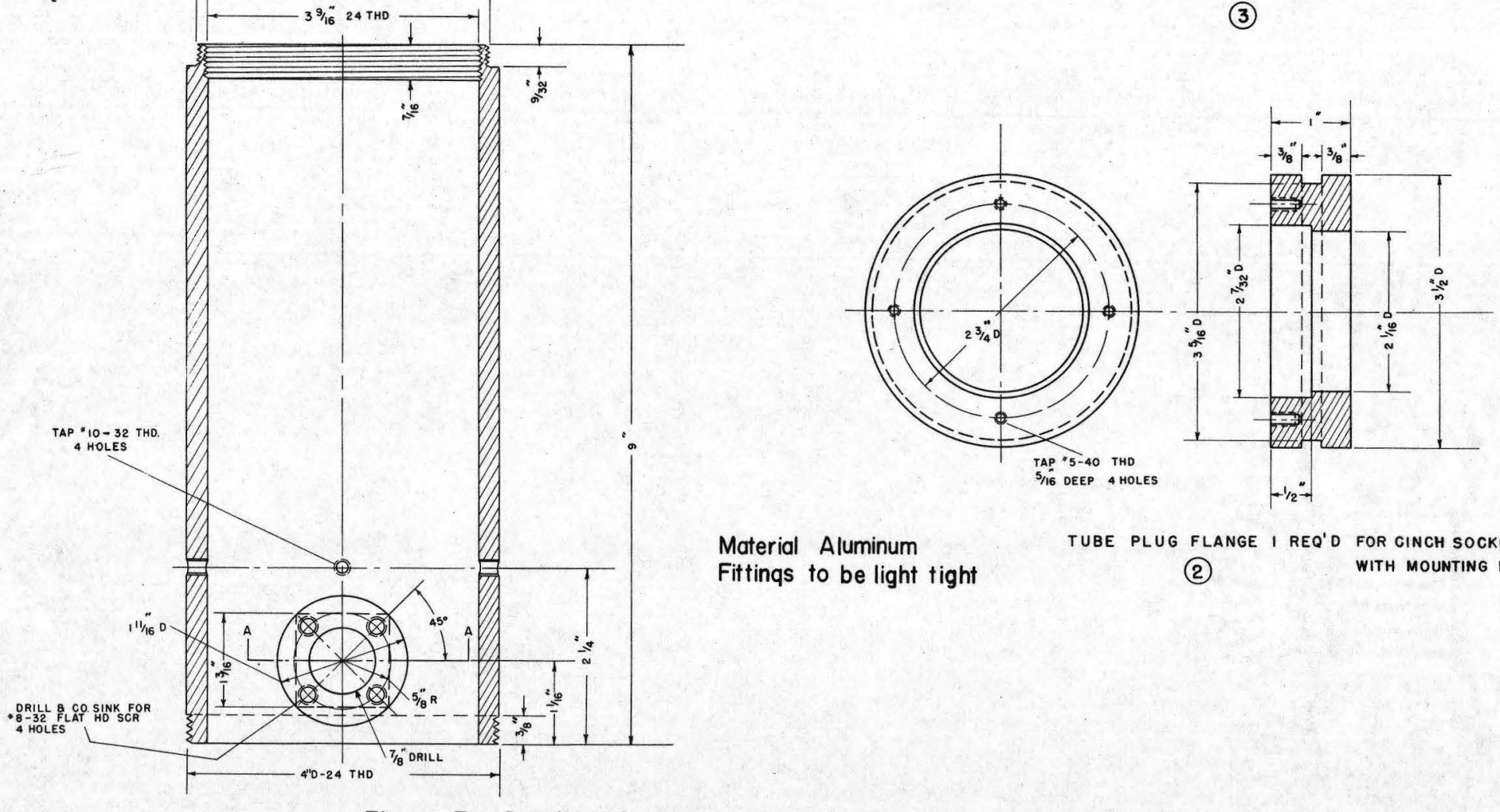

Material Aluminum

Fittinqs to be light tight
TUBE PLUG FLANGE I REQ'D FOR CINCH SOCKE T 3 M-4.

(2) WITH MOUNTING RING 3R-14

Figure 7-Details of construction of Phototube housing Type B 